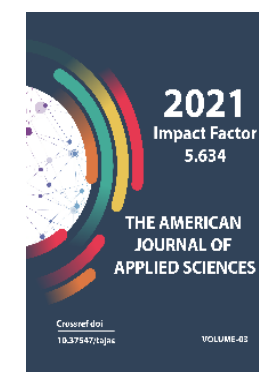

Journal Website: https://theamericanjou rnals.com/index.php/ta jas

Copyright: Original content from this work may be used under the terms of the creative commons attributes 4.0 licence.

\section{Low-Energy-Intensive Technology For Obtaining Sulphiro- Iron Clinkers And The Properties Of Cement Based On Their} Basis

\author{
Ruziev Negmat Ruzievich \\ Ruziev Negmat Ruzievich. PhD (Engineering). Joint Stock Company “Navoi Mining And \\ Metallurgical Combine", Uzbekistan
}

\begin{abstract}
Iskandarova Mastura Iskandarovna
Iskandarova Mastura Iskandarovna. DSc, Professor. Chief Researcher Of The Institute Of General And Inorganic Chemistry Of The Academy Of Sciences Of The Republic Of Uzbekistan

Mironyuk Nina Anatolyevna

Senior Researcher At The Institute Of General And Inorganic Chemistry Of The Academy of Sciences Of The Republic Of Uzbekistan

Makhsudova Nozima Dzhaparkhanovna

Makhsudova Nozima Dzhaparkhanovna, Junior Researcher At The Institute Of General And Inorganic Chemistry Of The Academy Of Sciences Of The Republic Of Uzbekistan
\end{abstract}

\title{
ABSTRACT
}

The results on the development of highly reactive compositions of raw mixtures and low-power technology for obtaining sulfo-iron clinkers of low-temperature firing with integrated use as components of natural and man-made waste, study of the properties of cements based on them are presented.

\section{KEYWORDS}

Phosphogypsum, hematite rock, carbonate waste from lime production, raw mix, low-temperature roasting, sulfo-iron clinker, a new type of cement, physical and mechanical properties.

\section{INTRODUCTION}

In the Republic of Uzbekistan there are large reserves of iron ore in the Jizzakh region (Chimkurgan deposit), in the Kuldzhuktau mountains - in the Navoi region and on the Kamyshbashinsky area - in the Fergana and Kashkadarya regions, as well as in the Republic of Karakalpakstan. In the Tashkent region, the
Surenatinskoe deposit is being studied, in which, along with magnetite ores, hematite ores are also developed. Hematite ores can be used as a corrective iron supplement. Their extraction is foreseen in the near future [68]. At present, much attention is paid to the disposal of large-tonnage industrial wastes, 
which also include phosphogypsum, large reserves of which are located in Almalyk and Samarkand. At the same time, as confirmed by numerous studies [1-3], phosphogypsum can serve as the main component of the raw mixture for the production of sulfomineral cements, as well as an effective additive for the production of decorative, sulfate-resistant, plugging, expanding and stressing cements on white and ordinary Portland - and sulfoclinker matrix.

In this regard, the processing of ferrous rocks in combination with sulfate-containing components into sulfate-ferrous cements using low-temperature technology is of significant interest in terms of reducing the cost of fuel and energy resources in the production of clinker and obtaining sulfateresistant, expanding and stressing cements.

The purpose of the work is the synthesis of low-temperature clinkers based on raw materials of Uzbekistan of natural and technogenic origin, the mineralogical composition of which includes sulfoaluminate, sulfosilicate, calcium sulfoferrites and the development of a technology for cements based on them, which are not inferior in strength indicators to those of traditional Portland cement.

\section{METHODS}

Determination of the chemical composition of raw materials was carried out in accordance with the requirements of GOST 5382-91 "Cements and materials for cement production. Analysis methods ". Calculation of the composition of sulfo-alumina raw material compositions and determination of the mineralogical composition of clinkers based on them were carried out according to the method developed by T.A. Atakuziev [3], setting the values of the saturation coefficient (KH) and sulfosilicate modulus (ns). To study the reactivity of new raw materials and to identify the optimum temperature for clinker synthesis, they were fired at temperatures of $800,900,1000,1100,1150,1200,1250,1300$, $1350^{\circ} \mathrm{C}$. Raw mixtures were fired in a laboratory furnace with silite heaters. Exposure time $-1 \mathrm{~h}$. The reactivity of sulfo-iron raw mixtures during roasting was estimated by the amount of free $\mathrm{CaO}$, determined by the ethyl-glycerate method. The phase composition of the firing products was determined by X-ray phase analysis using an XRD-6100 diffractometer (Shimadzu, Japan). The physicomechanical properties of sulfo-iron cements were determined on small sample cubes with a size of $4 \times 4 \times 4 \mathrm{~cm}$ with a composition of 1 : 0 .

\section{RESULTS}

For the synthesis of low-temperature sulfo-iron clinkers (SIC), the raw mixture based on ferrous ore, phosphogypsum and limestone was calculated with a saturation coefficient $\mathrm{KH}$ $=0.667$ and 0.8 ; sulfosilicate module $\mathrm{ns}=1.0$; 1.5; 2.0. Calculations have shown that, depending on the values of $\mathrm{KH}$ and $\mathrm{ns}$ of the raw charge, the content of iron ore in them ranges from 14.32 to $23.78 \%$, phosphogypsum from 16.16 to $33.68 \%$, limestone - from 50.03 to $62.84 \%$ (Table 1). The chemical composition of clinkers based on these raw materials includes up to $13.14 \% \mathrm{Fe}_{2} \mathrm{O} 3$ and up to $20.4 \% \mathrm{SO}_{3}$.

The synthesized sulfo-iron clinkers, according to the calculated data based on the results of the chemical analysis of the composition of the raw mixtures (Table 2 ), contain sulfominerals in 
The American Journal of Applied sciences (ISSN - 2689-0992)

Published: September 30, 2021 | Pages: 26-37

the following amounts (wt.\%): At $\mathrm{KH}=0.667$ and $n S=1.0-2.0$ : sulfoaluminate calcium $\mathrm{C}_{4} \mathrm{~A} 3 \mathrm{~S}$ 5.46 - 7.36; calcium sulfoferrite $C_{4} \mathrm{~F} 3 \hat{S} 14.53$ 19.55; calcium sulfosilicate $\mathrm{C}_{5} \mathrm{~S} 2 \mathrm{~S} 63.44$ - 73.0. With $\mathrm{KH}=0.80$ and $\mathrm{nS}=1.0-2.0: \mathrm{C}_{4} \mathrm{~A} 3 \hat{\mathrm{S}} 5.39$ 7.08; C4F3Ŝ 13.14-19.53; C5S2Ŝ 59.80 - 70.12 (Table 3 ). It should be noted that clinkers with $\mathrm{KH}=0.667$ and 0.80 differ insignificantly from each other in the content of $C_{4} A_{3} \hat{S}$ and $C_{4} F_{3} \hat{S}$, and the difference is significant in the content of $\mathrm{C}_{5} \mathrm{~S}_{2} \mathrm{~S}$. With $\mathrm{KH}=0.667$, the content of this mineral is 3-4\% higher than that of clinker with $\mathrm{KH}=0.8$. As the ns value increases, the content of unbound $\mathrm{CaSO}_{4}$ increases. Moreover, its content in SLA clinkers with $\mathrm{KH}=0.80$ is higher than with $\mathrm{KH}=0.667$.

Table 1

The substance composition of sulfo-alumina raw mixtures

\begin{tabular}{|c|c|c|c|c|}
\hline \multirow{2}{*}{$\begin{array}{c}\mathrm{KH} \\
\text { raw } \\
\text { composition }\end{array}$} & \multirow{2}{*}{$\begin{array}{c}\mathrm{n}_{\mathrm{s}} \text { raw } \\
\text { composition }\end{array}$} & \multicolumn{3}{|c|}{ Состав сырьевой композиции, масс. \% } \\
\hline & & limestone & ferrous ore & $\begin{array}{c}\text { phosphogypsu } \\
\text { m }\end{array}$ \\
\hline \multirow{3}{*}{0,667} & 1,0 & 58,74 & 23,78 & 17,43 \\
\hline & 1,5 & 54,07 & 19,79 & 26,14 \\
\hline & 2,0 & 50,03 & 16,29 & 33,63 \\
\hline \multirow{3}{*}{0,80} & 1,0 & 62,84 & 21,00 & 16,16 \\
\hline & 1,5 & 57,82 & 17,56 & 24,62 \\
\hline & 2,0 & 54,40 & 14,32 & 31,23 \\
\hline
\end{tabular}

Table 2

Calculated chemical composition of the clinkers' SIC

\begin{tabular}{|c|c|c|c|c|c|c|c|c|c|c|}
\hline \multicolumn{2}{|c|}{ Value } & \multicolumn{9}{|c|}{ Содержание оксидов, weight. \% } \\
\hline $\mathrm{KN}$ & $\mathrm{n}_{\mathrm{s}}$ & $\mathrm{SiO}_{2}$ & $\mathrm{Al}_{2} \mathrm{O}_{3}$ & $\mathrm{Fe}_{2} \mathrm{O}_{3}$ & $\mathrm{CaO}$ & $\mathrm{MgO}$ & $\mathrm{SO}_{3}$ & $\mathrm{P}_{2} \mathrm{O}_{5}$ & $\mathrm{R}_{2} \mathrm{O}$ & $\Sigma$ \\
\hline \multirow{3}{*}{0,667} & 1,0 & 18,75 & 3,69 & 13,14 & 50,05 & 1,58 & 11,29 & 0,04 & 1,10 & 100 \\
\hline & 1,5 & 17,18 & 3,16 & 10,83 & 49,63 & 1,44 & 16,21 & 0,53 & 0,96 & 100 \\
\hline & 2,0 & 15,86 & 2,77 & 8,86 & 49,28 & 1,30 & 20,40 & 0,67 & 0,84 & 100 \\
\hline & 1,0 & 17,53 & 3,55 & 11,91 & 53,27 & 1,68 & 10,62 & 0,34 & 1,04 & 100 \\
\hline
\end{tabular}


The American Journal of Applied sciences

(ISSN - 2689-0992)

Published: September 30, 2021 | Pages: 26-37

Doi: https://doi.org/10.37547/tajas/Volume03Issueo9-04

\begin{tabular}{|c|c|c|c|c|c|c|c|c|c|c|}
\hline 0,80 & 1,5 & 16,15 & 3,09 & 9,82 & 52,64 & 1,52 & 15,33 & 0,50 & 0,91 & 100 \\
\cline { 3 - 11 } & 2,0 & 14,95 & 2,70 & 8,01 & 52,15 & 1,39 & 19,30 & 0,63 & 0,81 & 100 \\
\hline
\end{tabular}

Table 3

Mineralogical composition of the clinker SIC

\begin{tabular}{|c|c|c|c|c|c|}
\hline \multicolumn{2}{|c|}{ Value } & \multicolumn{4}{|c|}{ Mineral content, weight \% } \\
\hline \multirow{2}{*}{$\mathrm{KN}$} & $\mathrm{n}_{\mathrm{S}}$ & $\mathrm{C}_{4} \mathrm{~A}_{3} \hat{\mathrm{S}}$ & $\mathrm{C}_{4} \mathrm{~F}_{3} \hat{\mathrm{S}}$ & $\mathrm{C}_{5} \mathrm{~S}_{2} \hat{\mathrm{S}}$ & $\mathrm{CaSO}_{4}$ \\
\hline \multirow{2}{*}{0,667} & 1,0 & 7,36 & 19,55 & 73,0 & 0,9 \\
& 1,5 & 6,30 & 17,76 & 68,72 & 7,24 \\
& 2,0 & 5,46 & 14,53 & 63,44 & 16,57 \\
\hline \multirow{2}{*}{0,80} & 1,0 & 7,08 & 19,53 & 70,12 & 3,27 \\
& 1,5 & 6,16 & 16,11 & 64,60 & 12,13 \\
& 2,0 & 5,39 & 13,14 & 59,80 & 27,67 \\
\hline
\end{tabular}

It is known that sulfate-containing minerals form at lower temperatures than minerals in Portland cement clinker. Calcium sulfoaluminate begins to form at $1150^{\circ} \mathrm{C}$. In the presence of iron compounds, this process can begin even earlier, since the presence of iron ions, as noted in the first chapter, accelerates the interaction of the components of the raw material mixture. Iron in the presence of calcium sulfate at low temperatures first forms mono- and then dicalcium ferrite, which with increasing temperature includes calcium sulfate in its structure [4-6]. The properties of sulfo-alumina raw materials, the rate of the mineral formation process, the temperature of the completion of clinker formation are largely determined by the type and properties of the iron and sulfate-containing components. Due to the fact that up to $23 \%$ of the raw material charges of the clinker SAL contain ironcontaining ore, the behavior of which during firing as the main component of the phosphogypsum-containing raw mixture has not yet been studied, it was necessary to investigate the reactivity and kinetics of mineral formation during firing new sulfoalumina raw material compositions in the temperature range of $700-1250^{\circ} \mathrm{C}$, with an interval of 100 to $1200^{\circ} \mathrm{C}$, and then with an interval of $50^{\circ}$ to $1250^{\circ} \mathrm{C}$.

To study this issue, briquettes from sulfo-iron raw materials with $\mathrm{KH}=0.667$ and 0.80 , with $\mathrm{nS}=1.0 ; 1.5 ; 2.0$ were fired at temperatures of $700,800,900,1000,1100,1200$ and $1250^{\circ} \mathrm{C}$ with an exposure of $1 \mathrm{~h}$ at a given temperature. The kinetics of $\mathrm{CaCO}_{3}$ dissociation and $\mathrm{CaO}$ assimilation during firing, as well as the formation of clinker minerals, were followed by X-ray phase analysis. The analysis of diffraction patterns showed that in the presence of ferrous ore in a sulfate-containing raw mixture, the process of mineral formation proceeds intensively: diffraction patterns of 
cakes of sulfo-ferrous raw mixtures with $\mathrm{KH}=$ $0.667, \mathrm{nS}=1.0$, fired at $700^{\circ} \mathrm{C}$, mainly reveal diffraction reflections of minerals 33 of the initial components: $\mathrm{Ca}(\mathrm{d} / \mathrm{n}=0.302 ; 0.227$; $0.208 ; 0.190 ; 0.186) \mathrm{nm}, \alpha-\mathrm{Fe}_{2} \mathrm{O}_{3}(\mathrm{~d} / \mathrm{n}=0.267$; $0.251) \mathrm{nm}, \beta-\mathrm{CS}(\mathrm{d} / \mathrm{n}=0.302) \mathrm{nm}, \gamma-\mathrm{CS}(\mathrm{d} / \mathrm{n}$ $=0.349,0.283,0.232) \mathrm{nm}, \mathrm{C}_{2} \mathrm{AS}(\mathrm{d} / \mathrm{n}=0.422)$ $\mathrm{nm}$. The increase in the intensity of the line with $\mathrm{d} / \mathrm{n}=0.302 \mathrm{~nm}$ is caused by the superposition of the lines of calcite and $\beta$ $\mathrm{CaSO}_{4}$. The presence of lines with $\mathrm{d} / \mathrm{n}=0.247$ $\mathrm{nm}$ in the diffractogram indicates that at a temperature of $700^{\circ} \mathrm{C}$, partial decomposition of $\mathrm{CaCO}_{3}$ occurs with the release of $\mathrm{CaO}$, and the presence of a line of low intensity with $d / n=$ $0.269 \mathrm{~nm}$ indicates the formation of a small amount of dicalcium ferrite. An increase in temperature to $800-900^{\circ} \mathrm{C}$ contributes to a significant decrease in the intensity of the main lines of calcite and $C \hat{S}$. At these temperatures, $\mathrm{CF}(\mathrm{d} / \mathrm{n}=0.278,0.268) \mathrm{nm}$ and $\mathrm{C}_{5} \mathrm{~S}_{2} \hat{\mathrm{S}}(\mathrm{d} / \mathrm{n}=$ $0.401 ; 0.282$; 0.256 ; 0.258$) \mathrm{nm}$ begin to form. The complete dissociation of $\mathrm{CaCO}_{3}$ with the release of free $\mathrm{CaO}$ and the interaction of the latter with the iron-, sulfate- and aluminatecontaining components of the charge occurs at a temperature of $1100^{\circ} \mathrm{C}$. The lines of calcite, calcium sulfate, hematite and gelenite completely disappear on the diffractogram. The appearance of diffraction reflections $\mathrm{C}_{4} \mathrm{~F}_{3} \hat{\mathrm{S}}$ $(\mathrm{d} / \mathrm{n}=0.268,0.254,0.188) \mathrm{nm}, \mathrm{C}_{5} \mathrm{~S}_{2} \hat{\mathrm{S}}(\mathrm{d} / \mathrm{n}=$ $0.453,0.346,0.333,0.311,0.2820 .260) \mathrm{nm}$, $\mathrm{C}_{4} \mathrm{~A}_{3} \hat{\mathrm{S}}(\mathrm{d} / \mathrm{n}=0.374) \mathrm{nm}$ is noted. As the temperature rises to $1200-1250^{\circ} \mathrm{C}$, the intensity of the lines of these compounds increases. Moreover, judging by the intensity of diffraction reflections, these minerals are completely formed at $1200^{\circ} \mathrm{C}$. The same tendency in mineral formation was noted during the firing of sulfo-iron raw materials with $\mathrm{KH}=0.8$ and $\mathrm{ns}=1.0$. The composition of the neoplasms in the firing products is identical to those of the cakes synthesized from the mixtures with $\mathrm{KH}=0.667, \mathrm{~ns}=1.0$. An increase in temperature above $1200^{\circ} \mathrm{C}$ leads to the decomposition of $\mathrm{C}_{4} \mathrm{~F}_{3} \hat{\mathrm{S}}$ with the formation of $\mathrm{C}_{2} \mathrm{~F}, \mathrm{C}_{2} \hat{\mathrm{S}}$ and free $\mathrm{CS}$.

This is also confirmed by the data of X-ray phase analysis of sulfo-ferruginous clinkers (SIC) with $\mathrm{KH}=0.667$ and 0.8 ; $\mathrm{ns}=1.0 ; 1.5$ and 2.0, synthesized at $1250^{\circ} \mathrm{C}$ (Fig.1).

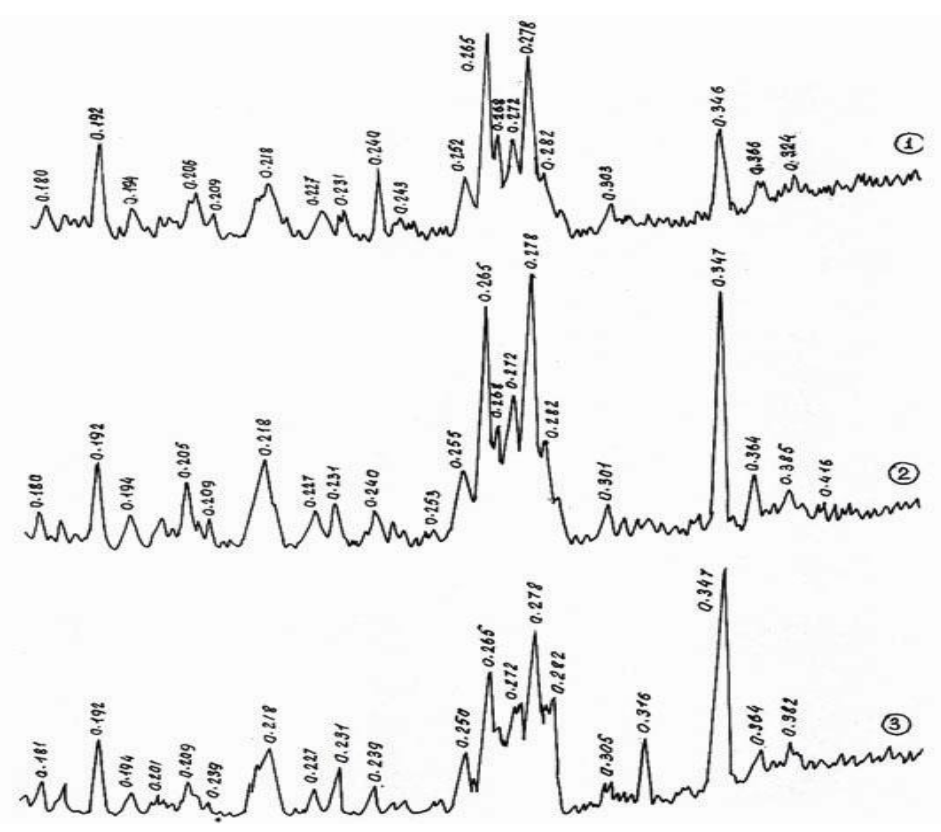

Rice. 1. Diffraction patterns of the SOL clinkers with $\mathrm{KH}=0.667$ and $\mathrm{nS}=1.0$ (1); 1.5 (2); 2.0 (3), synthesized at $1250^{\circ} \mathrm{C}$ 
Regardless of the $\mathrm{KH}$ and ns of the charge, at $1250^{\circ} \mathrm{C} \mathrm{C}_{4} \mathrm{~F}_{3} \hat{S}$ decomposes into $\mathrm{C}_{2} \mathrm{~F}$, $\mathrm{CaO}$, and $\mathrm{CaSO}_{4}$, which is clearly illustrated in Fig. 2, which shows strong diffraction reflections $\mathrm{C}_{2} \mathrm{~F}$ $(\mathrm{d} / \mathrm{n}=0.365 ; 0.278 ; 0.266 ; 0.206 ; 0.192$ and $0.182) \mathrm{nm}, \mathrm{CS}(\mathrm{d} / \mathrm{n}=0.349 ; 0.232) \mathrm{nm}$ and less intense reflections with $\mathrm{d} / \mathrm{n}=0.240 \mathrm{~nm}$, related to $\mathrm{CaO}$.

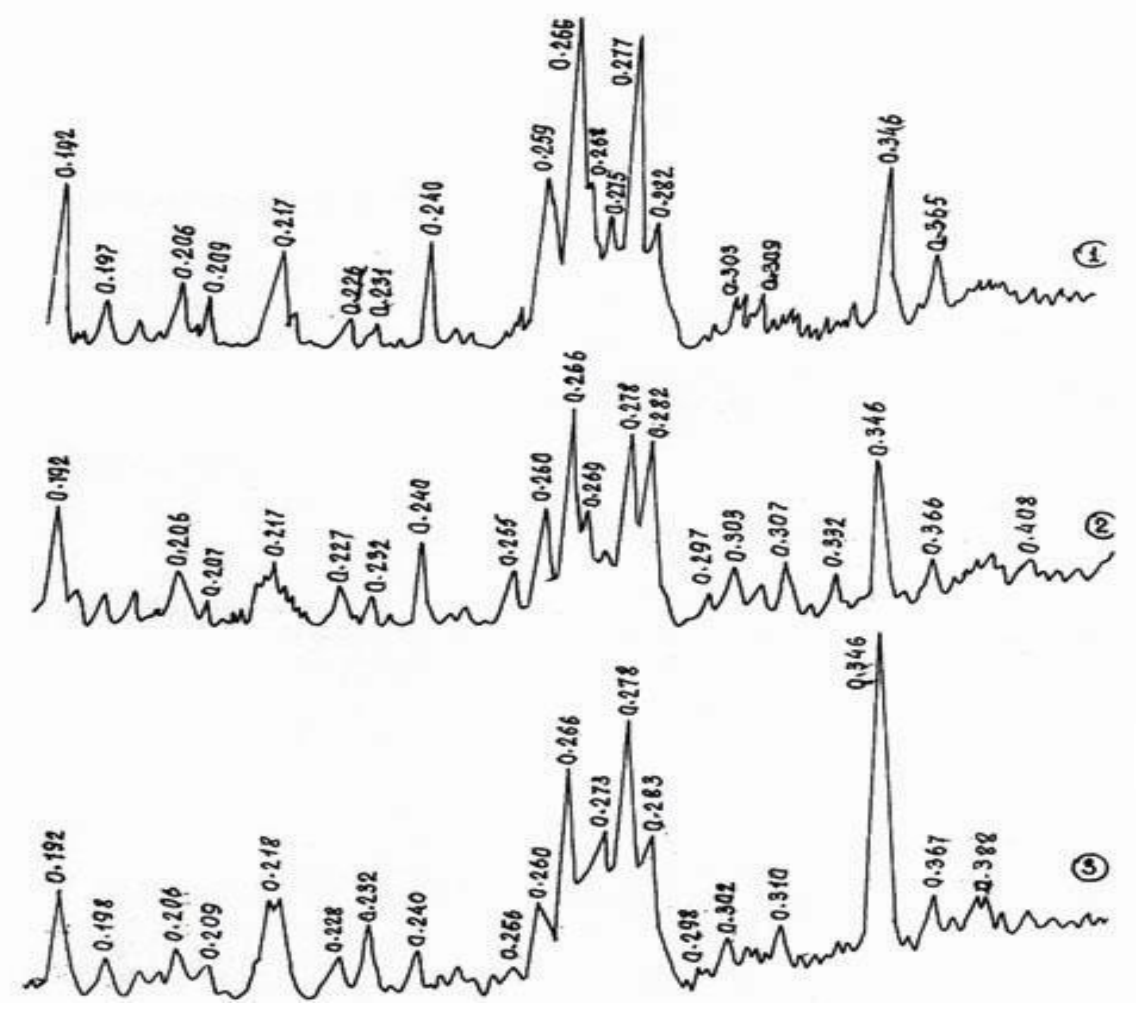

Rice. 2. Diffraction patterns of the SIC clinkers with $\mathrm{KH}=0.80$ and $\mathrm{nS}=1.0$ (1); 1.5 (2); 2.0 (3), synthesized at $1250^{\circ} \mathrm{C}$

The relief of the cleaved surface of the SIC clinkers with $\mathrm{KH}=0.667$ and with different ns, fired at $1200^{\circ} \mathrm{C}$, is characterized by the presence of formations of various shapes. At ns $=1.0$, the relief of the cleaved product of firing is represented by large crystals - blocks with a smooth surface, which is characteristic of the structure $\mathrm{C}_{5} \mathrm{~S}_{2} \hat{\mathrm{S}}$ (pic.3). 

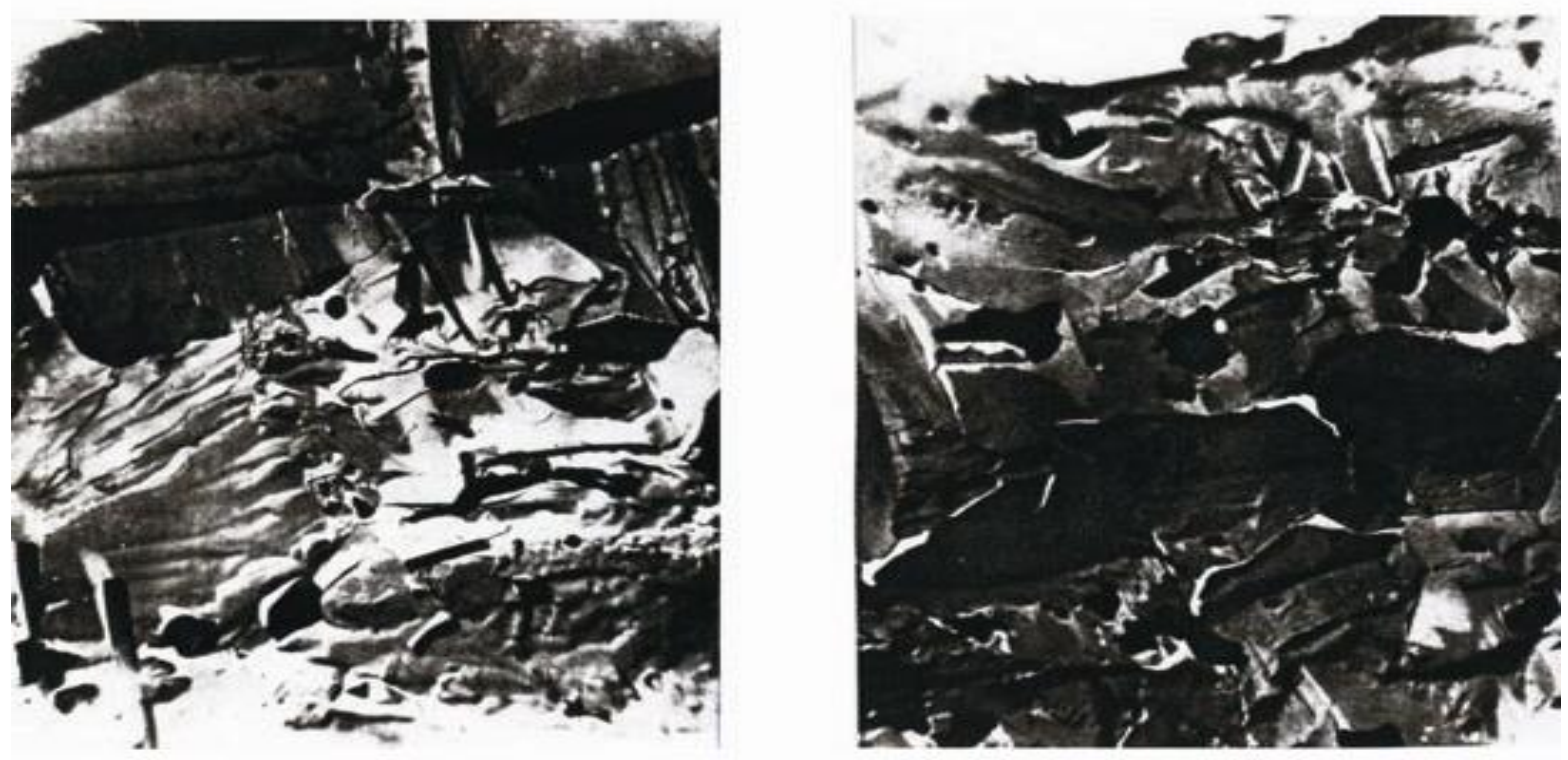

Rice. 3. Micrographs of replicas from the surface of the SIC clinkers with $\mathrm{KH}=0.667$ and $\mathrm{nS}=1.5$ (b) and 2.0 (c), synthesized at $1200^{\circ} \mathrm{C} . \times 5300$

Between the large elongated crystals, there are individual, smaller oval grains and small crystals of prismatic and trigonal shapes, apparently belonging to $\mathrm{C}_{4} \mathrm{~A}_{3} \hat{\mathrm{S}}$ and $\mathrm{C}_{4} \mathrm{~F}_{3} \hat{\mathrm{S}}$, respectively. With an increase in the ns value to 1.5, the surface of the relief of the blocks acquires a layered character, which indicates the dissolution of minerals in each other and a more durable structure of the SIC clinker.

The increase in the content of phosphogypsum in the raw material composition, i.e. an increase in the ns value to 2.0 promotes the formation of the clinker microstructure with a higher degree of dissolution of crystalline synthesis products on the surface of grains of the main mineral - $C_{5} S_{2} \hat{S}$. Prismatic and cylindrical crystals are visible between coarse grains and on their surface, often growing perpendicular to the surface of clinker grains, which can be attributed to $\mathrm{CaSO}_{4}$ crystals. The bulk of clinker is represented by grains of indistinct shapes, which indicates an increase in the defectiveness of the structure of the formed phases during firing in the presence of a large amount of sulfate ions. Recommendations on this matter have also been issued by the authors of [6-8], who note that the strength of sulfo-alumina cements depends on the basicity of clinkers: at $\mathrm{KH}=0.8$, the strength indicators are higher than at $\mathrm{KH}=$ $0.667 ; 0.9$ and 1.0 .

Determination of the setting time of sulfoalumina cements showed that the cements synthesized at $1250^{\circ} \mathrm{C}$ have slightly shorter setting times than the cements obtained at $1200^{\circ} \mathrm{C}$ (Table 4). So, the beginning of setting of cements based on SIC clinkers with $\mathrm{KH}=0.667$ and 0.8 , synthesized at $1200^{\circ} \mathrm{C}$, depending on ns, occurs in 58 minutes. -1 hour 42 minutes, end - after 1 hour 56 minutes. - 2 hours 05 minutes For cements from clinkers synthesized at $1250^{\circ} \mathrm{C}$, the onset of setting is in $15-28$ minutes, the end in $40-53$ minutes. Shorter setting times for SIC cements based on clinkers synthesized at $1250^{\circ} \mathrm{C}$ are due to the presence of a significant amount of $\mathrm{CaSO}_{4}$ in their composition, which, as shown by diffractograms, due to the partial decomposition of $C_{5} S_{2} \hat{S}$ into $C_{2} \hat{S}$ and $C \hat{S}$ in the presence of $\mathrm{Fe}_{3}+$ ions, as well as $\mathrm{C}_{4} \mathrm{~F}_{3} \hat{\mathrm{S}}$ into $\mathrm{C}_{2} \mathrm{~F}$ and $\mathrm{CS}$. 


\section{Table 4}

\section{Physicomechanical characteristics of SIC cements from clinkers synthesized by $1200^{\circ} \mathrm{C}$}

\begin{tabular}{|c|c|c|c|c|c|c|c|c|}
\hline \multirow{2}{*}{$\begin{array}{c}\mathrm{KH} \\
\text { Of clinker }\end{array}$} & \multirow[t]{2}{*}{$\mathrm{n}_{\mathrm{s}}$} & \multicolumn{2}{|c|}{$\begin{array}{l}\text { Setting time, } \\
\text { c - minutes }\end{array}$} & \multicolumn{5}{|c|}{ Compressive strength, MPa, through: } \\
\hline & & begin & end & 1 day & 3 day & 7 day & 28 day & 90 day \\
\hline \multirow{3}{*}{0,667} & 1,0 & $0-58$ & $1-56$ & 8,4 & 20 & 38 & 72 & 102 \\
\hline & 1,5 & $1-10$ & $1-59$ & 10,2 & 28 & 44 & 95 & 108 \\
\hline & 2,0 & $1-42$ & $2-02$ & 14,2 & 29 & 54 & 122 & 142 \\
\hline \multirow{3}{*}{0,80} & 1,0 & $1-08$ & $1-58$ & 8,2 & 16,0 & 30 & 58 & 84 \\
\hline & 1,5 & $1-42$ & $2-05$ & 8,8 & 22,0 & 34 & 71 & 98 \\
\hline & 2,0 & $1-46$ & $2-05$ & 9,6 & 26,0 & 40 & 92 & 116 \\
\hline $\mathrm{KH}=0,92$ & - & $3-50$ & 4-50 & 9,8 & 21,9 & 31,6 & 66,1 & 78,9 \\
\hline
\end{tabular}

The mechanical strength of the SIC cements was determined on small specimens with a size of $1.41 \times 1.41 \times 1.41 \mathrm{~cm}$ with a composition of 1: 0 , made by plastic molding. Samples stored for 1 day. in an air humid environment, they did not give in to demoulding due to rapid hardening and, apparently, due to a certain increase in volume. Therefore, the mode of preliminary air-wet hardening was reduced and in the next series of experiments the samples were released from the molds after 4 hours, after which they were transferred into water, where they continued to harden until the corresponding test period..

In accordance with the data in the table. 4, the strength of cements with $\mathrm{KH}=0.667$, obtained at a temperature of $1200^{\circ} \mathrm{C}$, uniformly increases with increasing $\mathrm{nS}$ values. So, for example, after 1 day. air-wet hardening, the strength of cements with $\mathrm{nS}=1.0$ was $8.4 \mathrm{MPa}$, and of cements with $\mathrm{nS}=1.5$ and 2.0, respectively, 10.2 and $14.2 \mathrm{MPa}$, which is 4.08 and $44.9 \%$ higher than the strength of Portland cement of Kizilkumcement JSC. With the time of hardening, the strength indices of SIC cements at all values of nS uniformly and steadily increase and, as a result, their branded strength ranges from 71 to $122 \mathrm{MPa}$, which is 7.4 - 84.85\% higher than the strength of ordinary Portland cement. This tendency towards an increase in the strength of sulfocomposites persists in subsequent periods, up to 90 days. With an increase in $\mathrm{KH}$ to 0.80 at $\mathrm{nS}=1.0$, a decrease in the strength parameters of the cement stone was noted up to 28 days. (Table 5). Decline of strength in comparison with the factory one in the period of 1-28 days. ranges from 6 to $30 \%$. By the age of 3 months, the cement stone is gaining a sufficiently high strength, which is $6.46 \%$ higher than that of Portland cement (Table 6). 
Table 5

Physicomechanical characteristics of SIC cements from clinkers synthesized by $1250^{\circ} \mathrm{C}$

\begin{tabular}{|c|c|c|c|c|c|c|c|c|}
\hline \multirow{2}{*}{$\begin{array}{c}\mathrm{KH} \\
\text { of clinker }\end{array}$} & \multirow[t]{2}{*}{$\mathrm{n}_{\mathrm{s}}$} & \multicolumn{2}{|c|}{$\begin{array}{l}\text { Setting time, } \\
\text { c-minutes }\end{array}$} & \multicolumn{5}{|c|}{ Compressive strength, MPa, through: } \\
\hline & & begin & end & begin & end & begin & end & begin \\
\hline \multirow{3}{*}{0,667} & 1,0 & $0-15$ & $0-52$ & 7,2 & 16,0 & 32,0 & 65 & 92 \\
\hline & 1,5 & $0-16$ & $0-50$ & 8,0 & 22,0 & 38,0 & 70 & 100 \\
\hline & 2,0 & $0-22$ & $0-53$ & 10,0 & 25,0 & 45,0 & 95 & 130 \\
\hline \multirow{3}{*}{0,80} & 1,0 & $0-25$ & $0-40$ & 7,3 & \multicolumn{4}{|c|}{ cracks - not tested } \\
\hline & 1,5 & $0-25$ & $0-42$ & 7,8 & \multicolumn{4}{|c|}{ cracks - not tested } \\
\hline & 2,0 & $0-28$ & $0-45$ & 8,8 & \multicolumn{4}{|c|}{ cracks - not tested } \\
\hline
\end{tabular}

Table 6

Relative strength of SIC cements from clinkers fired at $1200^{\circ} \mathrm{C}$

\begin{tabular}{|c|c|c|c|c|c|c|}
\hline \multirow{2}{*}{ KH } & \multirow{2}{*}{ KH } & \multicolumn{5}{|c|}{ Relative strength in relation to the strength of the PC,\%, through: } \\
\cline { 3 - 7 } & n & 1 day & 3 day & 7 day & 28 day & 90 day \\
\hline \multirow{2}{*}{$\begin{array}{c}\text { Portland } \\
\text { cement 0,92 }\end{array}$} & - & 100 & 100 & 100 & 100 & 100 \\
\hline \multirow{2}{*}{0,667} & 1,0 & 85,71 & 91,32 & 120,25 & 108,93 & 128.01 \\
& 1,5 & 104,08 & 127,85 & 139,24 & 131,94 & 136,88 \\
& 2,0 & 144,90 & 132,42 & 170,89 & 184,85 & 179,97 \\
\hline \multirow{2}{*}{0,80} & 1,0 & 83,67 & 70,06 & 94,04 & 87,75 & 106,46 \\
& 1,5 & 89,80 & 100,46 & 107,6 & 107,41 & 124,20 \\
& 2,0 & 97,96 & 118,72 & 126,58 & 139,18 & 147,02 \\
\hline
\end{tabular}


At values of $\mathrm{nS}=1.5$ and 2.0 after 1 day. a stone based on SIC cement is characterized by a slightly lower strength than Portland cement. However, these indicators are higher than that of SIC cement with $\mathrm{nS}=1.0$. Moreover, the higher the nS value, the higher the strength. Over time, the hardening process of SIC cements accelerates, and the stone on their basis gains a sufficiently high strength, by 7,28 and 90 days. superior strength of Portland cement, respectively, by 7.6 - 26.58; 7.4 - 39.18; $24.2-47.02 \%$.

When conducting research, Portland cement $M$ "400" of JSC "Kizilkumcement" was used as a base for comparison, which showed strength equal to 21.9 under experimental conditions on small samples; 31.6; 66.1 MPa, respectively, after 3; 7 and 28 days To translate the data obtained into standard samples, the conversion factor was found by dividing the strength indices of 28 daily standard samples by the indices of small samples of the same age, i.e. 400: $66.1=6.05$. To obtain an approximate grade of SIC cements, their strength indicators after 28 days. multiplied by this factor. For example, to determine the approximate grade of SIC cement with $\mathrm{KH}=$ $0.667, \mathrm{nS}=1.5$, its strength on small samples was multiplied by a factor of 6.05 and received $95 \times 6.05=574.75$. Therefore, the approximate grade of this cement is M "550". Thus, it is possible to determine the approximate grade and other compositions of the SIC cements.

An increase in the firing temperature of sulfoiron raw materials from $\mathrm{KH}=0.667$ to $1250^{\circ} \mathrm{C}$ led to a noticeable deterioration in the strength parameters of the SIC cements, which, regardless of the values of ns, after 1 day. hardening is 1.2-4.2 MPa lower than the strength of cements based on clinkers fired at $1200^{\circ} \mathrm{C}$, as well as factory Portland cement. With the age of hardening, the difference in the decline in strength indicators increases and amounts to 28 days. from 7.0 to $30.0 \mathrm{MPa}$. However, these indicators (for cements with $\mathrm{ns}=1.5$ and 2.0 ) are significantly higher than those of Portland cement.

Firing sulfo-iron raw materials with $\mathrm{KH}=0.80$ at all values of ns led to a decrease in the strength of cement samples based on these clinkers, which were stored for 1 day. in a humid air environment. After immersion in water after 3 days. samples of SIC cements at all values of ns were covered with a network of tiny cracks, which by 7 days. increased markedly in size. However, the samples did not collapse and did not crumble, which indicates that the samples gained a certain strength in the first periods of hardening.

The occurrence of cracks is probably due to the fact that the samples of SIC cements from clinkers synthesized at $1250^{\circ} \mathrm{C}$ have a sufficiently high expansion force. Their hardening under conditions of unlimited expansion due to the arising internal stresses is accompanied by the appearance of cracks. This is supposed to be facilitated by the simultaneous formation and intensive growth of crystals of the highly sulfate form of $\mathrm{C}_{4} \mathrm{~A}_{3} \hat{S}$ hydrate and gypsum dihydrate. There is a parallel hydration process and the interaction of components in the systems $\mathrm{C}_{2} \mathrm{~F}-\mathrm{CS}-\mathrm{H}_{2} \mathrm{O}$ and $\mathrm{C}_{4} \mathrm{~F}_{3} \hat{\mathrm{S}}-\mathrm{CS}-\mathrm{H}_{2} \mathrm{O}$ with the formation of calcium hydrosulfoferrites. It is known that hydration of calcium sulfoaluminoferrites leads to supersaturation of solutions with $\mathrm{Ca}^{2+}$ and $\mathrm{SO}_{4}{ }^{2-}$ ions, which contributes to the formation of iron-substituted ettringite-like phases, the amount and rate of formation of which depends on the composition of the matrix mineral $[6,10]$. Consequently, during the hydration of SIC cement based on clinker synthesized at $1250^{\circ} \mathrm{C}$ and having a multiphase mineralogical composition $\left(\mathrm{C}_{4} \mathrm{~A}_{3} \hat{\mathrm{S}}, \mathrm{C}_{4} \mathrm{~F}_{3} \hat{\mathrm{S}}, \mathrm{C}_{2} \mathrm{~F}\right.$, $\left.C_{2} \hat{S}, \quad C_{5} S_{2} \hat{S}, \quad C \hat{S}\right)$, complex physicochemical processes of hydration and hydrolysis of the constituent minerals occur with the formation, crystallization and recrystallization of new formations, structure formation and sulfocomposite formation. Intensive crystallization of ettringite, its iron-substituted analogue, gypsum dihydrate at the initial time 
causes the occurrence of internal stresses leading to deformation of the cement stone, in particular, to expansion and formation of cracks in the cement stone, which, under conditions of free expansion, does not have time to gain sufficient strength to withstand intense crystal growth and the resulting expansion force. These data are consistent with the previously obtained data and statements of V.V. Timasheva et al. That structural transformations are the driving force of the process of hydration of cement minerals when interacting with water and determine their chemical activity and physical and technical properties $[5,8,9]$.

\section{CONCLUSION}

It has been established that the optimal parameters for obtaining SIC clinkers and cements based on them are the values $\mathrm{KH}=$ $0.667, \mathrm{nS}=1.5-2.0$ and the firing temperature $1150-1200^{\circ} \mathrm{C}$. The hydraulic activity of SIC cements based on clinkers obtained by firing at the indicated temperatures of the optimal compositions of three-component raw mixtures based on limestone, phosphogypsum, hematite rock provides their grade 400-500.

\section{REFERENCES}

1. Atakuziev T.A., Iskandarova M.I., Talipov N.Kh., Tadzhieva D.F. Complex processing of phosphogypsum and other technogenic products into low-energyconsuming cements // Tr. XIV-Mendeleev Congress on General and App. chemistry. Moscow. :The science. 1989.v.2. - P112.

2. Iskandarova M.I., Tadzhieva D.F., Talipov N.Kh., Tairov Z.K. Highly efficient cements based on phosphogypsum // "Research on the use of phosphogypsum". - Moscow. 1989. no. 256 .-P146-155.

3. Iskandarova M.I., Jamalov Sh.O., Verdiyan M.A., Perov V.L. Structure formation and hardening of high-aluminate Portland cement in the presence of sulfate- containing additives // Tr. XIV-Mendeleev Congress on General and App. chemistry. -Moscow. : The science. 1989.v.2. - P66.

4. Krivoborodov Y.R., Samchenko S.V. Technology and properties of sulfoaluminoferritic clinkers // Tr. VIII AllUnion. Scientific and Technical Council on Chemistry and Technology of Cement. M.: INEK, 1991. -P323-327.

5. Timashev V.V., Osokin A.P., Larionov V.K. Synthesis and study of the properties of solid solutions of sulfoferrites and calcium sulfoaluminates //Tr. V All-Union. Scientific and Technical Council on Cement Chemistry. - M., 1990. -P70-73.

6. Osokin A.P., Krivoborodov Yu.R., Dyukova N.F. et al. Features of the technology of highly basic sulfoferrite-containing cements // Mater. XV All-Union. seminar meetings. - M.: Nllcement, 1990. -P48-50.

7. Timashev V.V., Osokin A.P., Akimov V.G., Krivoborodov Yu.R. Sulfo-iron cements // Abstracts. report VI All-Union. NTS in chemistry and technol. cement. - $M$.: VNIIESM, 1982. -P20-22.

8. Iskandarova MI, Ruzimova D. The problem of obtaining special cements on sulfoaluminoferritic basis on the basis of raw materials and waste from enterprises of Uzbekistan // Mater. NTK "New inorganic materials". - Tashkent, 2000.P53-55.

9. Feldman R.F. Relationship between the durability of cement and its porous structure, permeability and diffusion coefficient. Tr. VIII Int. Congr. on the chemistry of cement. - Rio de Janeiro, 1986. Vol.2.- P.336-353.

10. Ruziev N.R. Scientific foundations of the technology for producing low-power sulfo-alumina cements // Composite materials. No. 4. 2008 - P 85-86.

11. Ruziev NR, Iskandarova M., Negmatov SS, Rakhmanov MI, Khaidarov R. Technological bases for obtaining lowtemperature sulfo-alumina cements // Composite materials. No. 4. 2008 - P47-50. 
The American Journal of Applied sciences (ISSN - 2689-0992)

Published: September 30, 2021 | Pages: 26-37

Doi: https://doi.org/10.37547/tajas/Volume03Issueo9-04

12. V. Makhmudova, M. Iskandarova, Y. Ivanova, G. Chernov, N. Ruziev. Sunthesis and properties of sulfhoferrite calcium clinkers and low temperature cements on their basis //Jornal of Chemikal Technolo and Metallyrgy. Bulgary. 2011. 46, 2. - P. 151-154. 